\title{
Altered phenology and temperature sensitivity of invasive annual grasses and forbs changes autotrophic and heterotrophic respiration rates in a semi-arid shrub community
}

\author{
M. Mauritz and D. L. Lipson \\ San Diego State University, Department of Biology, 5500 Campanile Drive, San Diego, \\ CA 92182-4614, USA \\ Received: 9 March 2013 - Accepted: 24 March 2013 - Published: 3 April 2013 \\ Correspondence to: M. Mauritz (mmauritz@mail.sdsu.edu) \\ Published by Copernicus Publications on behalf of the European Geosciences Union.
}

\begin{abstract}
Many invasions, like the wide-spread establishment of annual grasses and forbs in semi-arid shrublands, are associated with climate change. In order to predict ecosystem carbon $(C)$ storage it is critical that we understand how invasion affects soil respira5 tion (Rt). Because plants and microbes have different seasonal dynamics, determining the relative contribution of autotrophic $(\mathrm{Ra})$ and heterotrophic $(\mathrm{Rh})$ respiration provides critical insight into soil $\mathrm{C}$ processes. Using automated soil respiration measurements and root exclusion cores we evaluated the moisture and temperature sensitivity of Rt and $\mathrm{Rh}$ and calculated the contribution of $\mathrm{Ra}$ in native shrub and invaded areas.

Invasion increased cumulative Rt by $40 \%$ from $695( \pm 51) \mathrm{g} \mathrm{C} \mathrm{m}^{-2}$ under shrubs to $1050 \mathrm{~g} \mathrm{C} \mathrm{m}^{-2}( \pm 44)$ in invaded areas. Cumulative Rh did not change but invasion altered the seasonal pattern of Rh. Throughout the season Rt and Rh responded positively to temperature increases when soils were wet and negatively when soils were dry. Invasion increased temperature sensitivity of Rt and Rh in wet soils and decreased tem15 perature sensitivity in dry soils. The altered temperature sensitivity of invasives was attributed largely to differences in phenology. Early phenology of invasive grasses caused rapid $\mathrm{Ra}$ increases early in the season; late phenology of invasive forbs resulted in the surprising maintenance of diurnal $\mathrm{Ra}$ and $\mathrm{Rh}$ signals despite high temperatures and low soil moisture.

20 Invasion extended the respiration season of the system. Ability of the invasive community to withstand high temperatures and drought could confer greater resilience if temperature and precipitation patterns in the region change. The high contribution of Ra by invasive annuals means ecosystem $\mathrm{C}$ storage will depend heavily on seasonal rainfall dynamics and productivity of invasive annuals. In semi-arid ecosystems even 25 small scale changes in plant community composition alter Rt, Ra and Rh and should be considered when attempting to predict Rt.
\end{abstract}




\section{Introduction}

Soils store large quantities of carbon $(\mathrm{C})$ and soil $\mathrm{CO}_{2}$ flux rates have most recently been estimated around $98 \pm 12 \mathrm{PgCyr}^{-1}$ (Bond-Lamberty and Thomson, 2010a). This makes soil respiration the largest source of $\mathrm{CO}_{2}$ to the atmosphere. As public, political

5 and commercial interest in global $\mathrm{C}$ management increases, the ability to accurately predict soil $\mathrm{C}$ dynamics is critical.

Plant invasions, often characterized by dramatic shifts in plant functional type, cause unprecedented changes to ecosystem function (D'Antonio and Vitousek, 1992). The success of invasive species is linked to changes in climate (Vitousek et al., 1996) and

10 invasion is likely to alter the way the plant community responds to future climate conditions (Chapin et al., 2009). However, the effect of invasion on soil respiration is poorly understood and the impact on regional and global $\mathrm{C}$ cycling is almost entirely unknown (Metcalfe et al., 2011).

Soil respiration (Rt: total respiration) depends on autotrophic $(\mathrm{Ra})$ and heterotrophic $15(\mathrm{Rh})$ respiration rates such that $\mathrm{Rt}=\mathrm{Ra}+\mathrm{Rh}$. Ra relies on $\mathrm{C}$ contained in recent photosynthates and has a shorter residence time than $\mathrm{Rh}$ which relies on the breakdown of older soil organic matter (SOM) (Hogberg 2001). Therefore the relative contribution of $\mathrm{Ra}$ and $\mathrm{Rh}$ to $\mathrm{Rt}$ affects $\mathrm{C}$ storage. Estimates of Ra contributions to Rt range from 10 $90 \%$, and differ based on plant functional type, seasonal water availability, temperature and plant phenology (Hanson et al., 2000).

Grassland $<->$ shrubland conversions are wide-spread in many arid and semi-arid ecosystems (Van Auken, 2000) altering C inputs, microbial community composition, soil microclimate and plant phenology (Jackson et al., 2000; Smith and Johnson, 2004). Fundamental differences in the structural and functional traits of shrubs and grasses, 25 such as root depth, litter quality or life history strategy alter soil respiration rates and C storage (Wolkovich et al., 2010; Davidson et al., 2006). However, the effects of grassland $<->$ shrubland conversions on the $\mathrm{C}$ cycle are not always consistent and appear to be site and climate dependent (Gill and Burke, 1999; Briggs et al., 2005; Goodale

6337

and Davidson, 2002). Furthermore the effects of conversion on Ra, Rh and Rt are largely unknown.

Broadly speaking Rt depends on temperature and ecosystem productivity (Raich and Tufekcioglu, 2000; Bond-Lamberty and Thomson, 2010b). But in arid and semi-arid 5 ecosystems water constrains biological activity and soil moisture often confounds or overrides temperature effects on Rt (Davidson et al., 1998; Lellei-Kovacs et al., 2011). Long and short lived plants (Huxman et al., 2004), roots and microbes all respond differently to temperature (Boone et al., 1998) and moisture (Aanderud et al., 2011). Ra contributions typically increase with temperature when soils are wet and plants are ac-

10 tive, but as soils dry the system becomes dominated by Rh (Tang and Baldocchi, 2005; Carbone et al., 2011). One comparison between annual grasses and native shrubs in a cold semi-arid desert found that greater $\mathrm{C}$ allocation to roots increased $\mathrm{Ra}$ in annual grasses (Carbone and Trumbore, 2007) and seasonal patterns in Rt were driven by Ra (Carbone et al., 2008). It is difficult to predict how $\mathrm{Ra}$ and $\mathrm{Rh}$ will respond to tempera-

15 ture and precipitation based on Rt alone (Davidson et al., 2012; Savage et al., 2013). Partitioning of Rt provides greater understanding of ecosystem $\mathrm{C}$ dynamics and why Rt changes with plant functional type.

The goal of this study was to determine the effect of invasion on soil respiration in Coastal Sage Scrub (CSS), a native semi-arid shrub community in southern Califor20 nia. The invasive annual grasses and forbs which become established in CSS contrast starkly with the shrubs in above ground structure, life-history and phenology. Previous studies in CSS show that invasion alters microbial community composition (Siguenza et al., 2006; El Souki, 2007) likely due to changes in leaf litter quality and quantity, which in turn increases $\mathrm{C}$ and $\mathrm{N}$ retention (Wolkovich et al., 2010). We were particularly in25 terested in how invasion affects the temperature and moisture sensitivity of Rt and Rh because altered temperature and moisture sensitivity points to underlying differences in microbial community composition, plant phenology and C substrate supply (Graf et al., 2011; Mahecha et al., 2011; Reich, 2010). We partitioned soil respiration into $\mathrm{Rh}$ and $\mathrm{Ra}$ components using root exclusion treatments under shrubs and in invaded 
areas. High frequency data were collected in order to capture dynamic seasonal transitions and include rain events to provide accurate estimates of seasonal soil $\mathrm{CO}_{2}$ loss from shrub and invaded areas (Vargas et al., 2011). The native perennial shrubs were expected to respond differently to soil moisture and temperature conditions compared

5 to the invasive annuals; however the direction of change was uncertain. Based on one previous study (Wolkovich et al., 2010) we predicted that Rt would be higher under rapidly growing invasive annuals. Because annual grasses germinate rapidly following the first large rainfall event of the season (Bartolome, 1979) we expected more early season $\mathrm{Ra}$ in invaded areas.

\section{Materials and methods}

\subsection{Site description}

This study was conducted at the San Diego State University Santa Margarita Ecological Reserve in Riverside County, CA ( $33^{\circ} 26^{\prime} 29.88^{\prime \prime} \mathrm{N}, 117^{\circ} 9^{\prime} 51.38^{\prime \prime} \mathrm{W}$ and $\left.393 \mathrm{~m}\right)$. The site was flat and roughly $25 \mathrm{~m} \times 10 \mathrm{~m}$. The central area was dominated by invasive annuals and native shrubs formed the perimeter of the patch. The area has not burned in the last 50 years. The climate is Mediterranean; summers are hot and dry, winters are cool and receive the majority of rainfall. In the two growing seasons that the study was conducted, total precipitation for the area was $380 \mathrm{~mm}$ in $2009 / 2010$ and $600 \mathrm{~mm}$ in $2010 / 2011$ with a mean temperature of $17^{\circ} \mathrm{C}$ in both years

20 (www.ncdc.noaa.gov), compared to a regional long term average of $17^{\circ} \mathrm{C}$ and $420 \mathrm{~mm}$ since 1895 (www.ncdc.noaa.gov). The soil is Las Posas rocky loam (NRCS Web Soil Survey) which tends to be moderately deep and well drained; weathered bedrock is at 50-60 cm depth (https://soilseries.sc.egov.usda.gov/OSD_Docs/L/LAS_POSAS.html). Coastal Sage Scrub (CSS) vegetation is dominated by the native shrubs Artemisia 25 californica, Eriogonum fasciculatum and Salvia mellifera. Intershrub spaces contain invasive annual grasses Bromus madritensis var. rubens and forbs Centaurea solstitialis

6339

and Hirschfeldia incana. The grasses have early phenology, germinating following first rainfall and senescing when soils dry and temperatures get hot in June. Forbs remain active well into July, even after soils are dry and temperatures are hot. The native shrubs are perennial, grow from February to May (Gray and Schlesinger, 1981) and 5 are dormant over the summer. Pre-invasion inter-shrub patches would have consisted of bare soils, biological soil crusts, bunch grasses and spring-flowering native annual forbs.

\subsection{Respiration measurements}

Soil respiration was measured using an LI-8100 Automated Soil $\mathrm{CO}_{2}$ flux system (LICOR). Respiration was measured under the canopy of 4 shrubs and in 4 invaded, intershrub patches at least $2 \mathrm{~m}$ apart. Every four hours a two minute flux measurement was taken. Soil moisture (volumetric water content $=$ VWC) and temperature $\left({ }^{\circ} \mathrm{C}\right.$ ) were measured at $0-5 \mathrm{~cm}$ depth inside every collar, concurrent with respiration measurements. Data was recorded for two growing seasons, February 2010-June 2010 and Septem5 ber 2010-July 2011. All collars were installed following the first rainfall in December 2009 and soils allowed to acclimate before measurements were initiated on 9 February 2010. In September 2010 measurements were resumed slightly before the first rainfall event. Measurements in both years terminated at the end of the growing season after invasive annuals senesced, midday temperatures approached $50^{\circ} \mathrm{C}$, further 20 rain was unlikely and all respiration rates had converged close to $1 \mu \mathrm{mol} \mathrm{CO}_{2} \mathrm{~m}^{-2} \mathrm{~s}^{-1}$.

Total respiration (Rt) was partitioned into heterotrophic $(\mathrm{Rh})$ and autotrophic $(\mathrm{Ra})$ components using root exclusion treatments. To measure $\mathrm{Rh}$, root exclusion cores, constructed out of $20 \mathrm{~cm}$ diameter PVC pipe, were installed to $30 \mathrm{~cm}$ depth. Rt was measured in collars, made from the same PVC, installed to $5 \mathrm{~cm}$ depth so that the 25 vegetation and root structure were undisturbed. Root exclusion and total respiration collars were immediately adjacent to each other. Thus, for each pair of chambers:

$\mathrm{Ra}=\mathrm{Rt}+\mathrm{Rh}$ 
Root biomass was determined at $0-15 \mathrm{~cm}$ and $15-30 \mathrm{~cm}$ when the chambers were removed in August 2011. Based on the root biomass and assuming that the root biomass continues to decline at the same rate from $0-15 \mathrm{~cm}$ to $15-30 \mathrm{~cm}$ until weathered bedrock at $60 \mathrm{~cm}$, we estimate that $90 \%$ of shrub roots and $98 \%$ of invasive roots

5 are in the top $30 \mathrm{~cm}$.

\subsection{Data processing}

$\mathrm{CO}_{2}$ concentrations were measured every 10 s during each 2 min interval. Fluxes were calculated by fitting exponential curves to each 2 min measurement using Licor 8100 FileViewer software (Version 2.0.0, LI-COR Inc. 2004-2006). Flux values with an ex10 ponential $r^{2}$ value less than 0.97 or a coefficient of variation $(\mathrm{CV})>2$, were removed. Measurements that did not pass these criteria were mainly due to incomplete chamber closure, broken tubing, power failure or instrument malfunction; approximately $15 \%$ of all measurements were removed using these criteria.

Further quality control was conducted visually using Matlab (Version 7.4.0 R2007a,

15 The MathWorks Inc. 1984-2007) to look for flux rates that had acceptable line fits but produced unreasonable flux values. Following Savage et al. (2008), fluxes were removed if the flux pattern or value appeared uncharacteristic compared to all the other chambers. Before removing erratic points the environmental conditions were considered in order to evaluate whether unusual flux rates were occurring at a particular time of day, temperature or soil moisture. For most chambers less than $4 \%$ of the data was removed this way, but for one chamber up to $20 \%$ of the data had to be removed.

Daily average fluxes were calculated for $\mathrm{Rt}, \mathrm{Rh}$ and expressed as $\mu \mathrm{mol} \mathrm{CO}_{2} \mathrm{~m}^{-2} \mathrm{~s}^{-1}$. Daily average Ra was calculated at each $4 \mathrm{~h}$ time point using Eq. (1), and expressed as a percent of Rt. At the end of the growing season soil respiration is very low and 25 spatial variability resulted in some $\mathrm{Rh}>\mathrm{Rt}$. In the rare cases this occurred, Ra was not calculated.

Soil moisture, soil temperature and chamber temperature data were also quality controlled. Some values could be removed due to obvious sensor failure while others were 6341

removed based on comparison to other chambers, comparison with air temperatures and knowledge of rain events. For example most soil and chamber temperatures less than $0^{\circ} \mathrm{C}$ and greater than $50^{\circ} \mathrm{C}$ were removed. When soil moisture or temperature was missing due to prolonged instrument failure, data was filled using averages from 5 the 3 other chambers in the same treatment. Soil moisture (percent of VWC) and temperature $\left({ }^{\circ} \mathrm{C}\right)$ are presented as weekly averages to show seasonal changes in soil conditions and evaluate the effect of plants and root exclusion on soil microclimate.

Because accurate soil flux measurements depend on accurate chamber temperature measurements, fluxes with failed chamber thermistors were corrected. Av10 erage chamber temperature was calculated from the other 3 chambers in the same treatment and the following formula was used to adjust the flux value: Fcor$\mathrm{rect}=\mathrm{Fbad} /((\mathrm{Tbad}+273.15) /($ Tcorrect +273.15$))$. In one chamber the thermistor never recorded accurate temperatures and all fluxes were corrected. Most other chambers only had episodic failure before thermistors were replaced. Approximately $16 \%$ of all

15 flux measurements were corrected this way.

\subsection{VWC probe calibration}

VWC measurements were calibrated using gravimetric water content (GWC) measured from soil. Soil cores $15 \mathrm{~cm}$ deep were collected once a month adjacent to each of the collar pairs. GWC was converted to VWC using soil bulk density of $1.4 \mathrm{~g} \mathrm{~cm}^{-3}$. VWC 20 was corrected using a linear fit $\left(r^{2}=0.472\right)$. The offset between VWC and GWC was consistent over all months with the exception of late spring when soils dried rapidly and the $0-5 \mathrm{~cm}$ soils measured by VWC were much drier than the $0-15 \mathrm{~cm}$ soil measured by GWC. These points were excluded from the regression.

\subsection{Statistical analysis}

25 Statistical analyses were performed using SYSTAT (Version 12, Systat Software Inc. 2007) and all variables were tested for normality and homoscedascity. Daily average 
$\mathrm{Rt}, \mathrm{Rh}$ and Ra were natural log (In) transformed to meet assumptions of ANOVA and regression.

\subsubsection{Effect of vegetation type and root exclusion on soil microclimate}

Microclimate differences due to presence of invasives or shrub (vegetation type) and

$5 \mathrm{Rt}$ vs. Rh (root effect) were investigated using weekly averages. Weekly averages reduced temporal autocorrelation, reflecting seasonal trends rather than daily variation. Consecutive weeks were grouped by season and repeated measures analysis of variance (RM ANOVA) was used to determine the between-group effect of vegetation type and treatment in each season.

\section{$10 \quad$ 2.5.2 Effect of invasion on flux rates}

The effects of invasion (vegetation) and root exclusion (roots) were evaluated based on cumulative respiration rates, seasonal responses to soil moisture and temperature and diurnal respiration patterns. Cumulative Rt and Rh were compared between invaded areas and shrubs for one entire growing season, September 2010-August 2011 using

15 ANOVA and Tukey's HSD posthoc test.

\subsubsection{Soil moisture and temperature effects on soil respiration patterns}

The relationships among $\mathrm{Rt}$ and $\mathrm{Rh}$, temperature and moisture were explored using regression analysis. Moisture and temperature were considered separately using quadratic fits:

In Rt or $\mathrm{Rh}=B_{0}+B_{1} \cdot \mathrm{VWC}+B_{2} \cdot \mathrm{VWC}^{2}$

In Rt or $\mathrm{Rh}=B_{0}+B_{1} \cdot$ temp $+B_{2} \cdot$ temp ${ }^{2}$

Soil moisture and temperature were highly correlated across seasons. The data was therefore split into soil moisture categories to reduce VWC and temperature 6343

co-linearity. Based on flux and VWC relationships (Eq. 2), the following soil moisture categories were determined: VWC $<10 \%$ (soil moisture is limiting), VWC $=10-15 \%$ (soil moisture not limiting) and VWC $>15 \%$ (soil moisture near saturation). Within each of these VWC categories, VWC and temperature were not correlated and the relative

5 importance of moisture and temperature for predicting flux in each soil moisture category could be evaluated using partial correlations.

The temperature responses of Rt and Rh in each VWC category were evaluated using linear regression. The effects of vegetation type and root exclusion on fluxtemperature relationships were determined by ANCOVA.

10 The temperature responses of $\mathrm{Ra}$ in $\mathrm{VWC}>10 \%$ and $\mathrm{VWC}<10 \%$ were determined by linear regression using average $\mathrm{Ra}$ values from each of the four replicate chambers for shrubs and invaded areas.

The effects of vegetation type and root exclusion on diurnal respiration were evaluated separately for each of three time periods, spring (11-21 February 2010), late spring (1-10 May 2010) and summer (1-10 June 2010), using RM ANOVA.

\section{Results}

\subsection{Respiration patterns were highly seasonal}

Soil respiration was dynamic with large seasonal variation. Rt had more pronounced spikes and larger seasonal variation than Rh (Fig. 1). Throughout the season soil res-

20 piration peaks occurred during and immediately after rain events but were dampened compared to the first pulse of the season. Following the first rain event of the season respiration rates increased rapidly but then declined as temperatures dropped in the winter, despite high soil moisture. In the spring respiration rates were at their highest when soils were warm and water was not limiting. During the summer respiration rates were very low and $\mathrm{Rt}$ and $\mathrm{Rh}$ in both vegetation types converged. 


\subsection{Invasion increased respiration rates}

Rt in invaded areas exceeded Rt under shrubs throughout the measurement period (Fig. 1a). Rt was most similar between invasives and shrubs in summer, at the end of the growing season and prior to the first rain events of the season (June-

5 September/October). This pattern is generally supported by RM ANOVA analysis of weekly fluxes (data not shown). Invasion also altered the relative contribution of Rh. In winter Rh under shrubs exceeded Rh in invaded areas, despite colder soils. As temperatures increased, and invaded areas became hotter than shrubs, Rh in invaded areas overtook Rt under shrubs and remained higher through the end of season (Fig. 1b).

10 This trend was consistent in both years, although the differences in Rh were generally not significant (RM ANOVA on weekly averages, results not shown). The inter-annual consistency indicates that seasonal microbial community dynamics differed between invasives and shrubs; further supported by the altered Rh temperature response in invaded areas (see below).

\subsection{Autotrophic contribution varied seasonally and was higher in invaded areas}

Ra contribution varied substantially throughout the season (Fig. 1C). During the main growing season Ra ranged from $50-80 \%$ of Rt. Invaded areas were at the upper end of this range and shrubs were at the lower end of this range. Differences between invaded areas and shrubs were particularly large during the winter. Invasive Ra was 20 around $70 \%$ of Rt, while shrub Ra was much lower, around $30 \%$. In the driest summer months Ra contribution rapidly dropped to $10-20 \%$ of total respiration as Rt and Rh converged at respiration rates less than $1 \mu \mathrm{MCO}_{2} \mathrm{~m}^{-2} \mathrm{~s}^{-1}$ (Fig. 1C).

\subsection{Invasion increased cumulative respiration rates}

Invaded areas had significantly higher cumulative Rt from September 2010 to Au25 gust 2011 compared to shrubs, $1050 \mathrm{~g} \mathrm{Cm}^{-2}( \pm 44)$ and $695( \pm 51) \mathrm{gC} \mathrm{m}^{-2}$ respectively

6345

(Tukey's HSD, $p<0.001$; Fig. 2). Cumulative Rh did not differ between invaded areas and shrubs (Tukey's HSD, $p=0.988$; Fig. 2). In order to make a fair comparison between the two years, cumulative fluxes were also calculated during the main growing season of each year when there were no large data gaps. From March-June of

5 both years there was no difference in cumulative Rt (ANOVA year effect, $p=0.190$; Table S1) or Rh (ANOVA year effect, $p=0.266$; Table S1). Between March-June 2009/2010 and 2010/2011 cumulative Rt in invaded areas was still significantly higher than shrubs (ANOVA vegetation effect, $p<0.001$ ) but the difference in $C$ respired was small compared to the whole growing season. Thus increased invasive respiration was 10 mainly due to differences in respiration outside the main growing season.

\subsection{Invasion altered soil microclimate}

Soil temperature and moisture patterns were highly seasonal. Weekly winter soil temperatures were as low as $7-10^{\circ} \mathrm{C}$, and peaked in the summer around $30^{\circ} \mathrm{C}$ (Fig. 3a). Diurnal temperatures regularly rose above $30^{\circ} \mathrm{C}$ and dropped as low as $2^{\circ} \mathrm{C}$ (data not 15 shown). Soil moisture was highest in the winter and spring and declined rapidly into the summer (Fig. 3b). Soil moisture was driven by the size and distribution of rain events, rising rapidly in response to rainfall and dropping again to pre-rainfall levels after a few days.

Invaded soils were warmer throughout the entire year (Fig. 3a), particularly evident

20 in spring (vegetation $p<0.01$, Table 1). In contrast, vegetation type did not affect soil moisture (vegetation $p>0.05$, Table 1 , Fig. $3 b$ ). In root exclusion treatments, where there was no vegetation cover, soils tended to be drier but this effect was not significant (root treatment $p>0.05$, Table 1, Fig. 3b). 


\subsection{Respiration rates depended on the interaction between soil moisture and temperature}

Soil respiration depended on soil moisture and temperature and generally speaking Rt and $\mathrm{Rh}$ in invaded and shrub areas were constrained by extremes in moisture and

5 temperature. However, when the sensitivity of Rt and Rh to moisture and temperature are considered in more detail, distinct differences between shrubs and invasives emerge. Moisture and temperature were strongly correlated and the effects on respiration were non-linear. A quadratic soil moisture curve explained $46 \%$ of shrub and $43 \%$ of invasive Rt, and $21 \%$ of shrub Rh but none of the variation in invasive Rh (Fig. 4,

10 Table S2). The effect of soil moisture on respiration had three distinct phases. When VWC $<10 \%$, moisture was limiting and respiration increased with VWC. At VWC 10$15 \%$ there was no effect of soil moisture on respiration and when VWC > $15 \%$ there was a slight negative relationship as the soils reached saturation (Fig. 4).

VWC and temperature predicted Rt almost interchangeably because VWC and tem15 perature were so strongly correlated over the entire season. Rh on the other hand was explained slightly better by temperature, $27 \%$ for shrubs and $19 \%$ for invasives (Table S2). When soil moisture and temperature were considered together, with an interaction term, the explanatory power improved to $56 \%$ for shrub and $58 \%$ for invaded Rt and $33 \%$ for shrub and $27 \%$ for invaded Rh (Table S2 \& Figs. 4 and 5). Respi-

20 ration responded to temperature in two different ways, positively at low temperatures and negatively at high temperatures (Fig. 5). These two temperature response phases overlapped with a $10 \%$ VWC threshold. Partial correlation coefficients show that the importance of temperature as a predictor decreased as soils dried. At VWC $>10 \%$, soil temperature accounted for all the explainable variation in flux. At VWC $<10 \%$ tem-

25 perature added no explanatory power to soil moisture (Table S3). Without water no biological activity is possible so the effect of temperature on respiration was confounded with soil moisture.

6347

\subsection{Invasion altered the temperature sensitivity of soil respiration}

Invasion altered the temperature sensitivity of Rh and Rt (Fig. 5, Table 2). When the soil was wet $\mathrm{Rh}$ and $\mathrm{Rt}$ in invaded areas responded more rapidly to temperature than shrubs. In contrast, when the soil was dry, Rh and Rt in shrubs responded more rapidly

5 to temperature. Invasion also increased the apparent optimum temperature threshold of respiration (Fig. 5). Invaded areas had an Rt threshold at $18^{\circ} \mathrm{C}$ compared to $15^{\circ} \mathrm{C}$ under shrubs and an Rh threshold of $21^{\circ} \mathrm{C}$ in invaded and $16^{\circ} \mathrm{C}$ in shrub areas (Fig. 5). The effect of invasion on the temperature response of Rh and Rt will briefly be considered for each VWC category:

\section{3.7 .1 Soil moisture $>15 \%$}

VWC $>15 \%$ describes conditions following rain events when soil moisture peaked around $20 \%$ and gradually declined in the weeks following (Fig. 2b). Rt was significantly more responsive to temperature increases in invaded areas than under shrubs (ANCOVA, veg $\times$ temp, $p=0.001$, Table 2), while the Rh response to temperature in 15 invaded and shrub areas did not differ significantly (ANCOVA, veg $\times$ temp, $p=0.116$, Table 2).

\subsubsection{Soil moisture $10-15 \%$}

VWC $10-15 \%$ was typical during winter and spring as well as during late season rain events (Fig. 2b). In invaded areas Rt increased more rapidly with temperature and was 20 significantly more responsive to temperature compared to shrubs (Fig. 5a; ANCOVA, veg $\times$ temp $p<0.05$, Table 2). Under shrubs Rt declined at temperatures greater than $15^{\circ} \mathrm{C}$, despite sufficient soil moisture (Fig. $5 \mathrm{c}$ ), which is why the linear temperature response fitted the data poorly. In invaded areas $\mathrm{Rh}$ increased more rapidly with temperature and rose to a higher respiration rate compared to shrubs (Fig. 5c, d; ANCOVA, 25 veg $\times$ temp $p<0.001$, Table 2). At VWC $10-15 \% r^{2}$ of the lines were lower than at 
VWC $>15 \%$. This is likely to be because VWC $10-15 \%$ spans more varied parts of the growing season than VWC $>15 \%$. VWC 10-15\% includes times when factors such as phenology or soil substrate supply may influence respiration rates.

\subsubsection{Soil moisture $<10 \%$}

5 VWC $<10 \%$ represented transitions from spring to summer and summer to fall as well as long rain intervals during the spring. The lowest soil moistures occurred at the beginning and end of summer when most of the invasive vegetation had senesced and the native vegetation was dormant. The large temperature range, $10-35^{\circ} \mathrm{C}$, reflects the variety of seasons captured by $\mathrm{VWC}<10 \%$. Rt and Rh declined more rapidly and con-

10 sistently under shrubs than invaded areas (ANCOVA, veg $\times$ temp $p<0.001$, Table 2). Rt rates in shrubs were predicted better than Rt in invaded areas, as illustrated by the higher $r^{2}$ values (Fig. $5 \mathrm{a}$ vs. b). Based on partial correlations, when $\mathrm{VWC}<10 \%$, Rt was more dependent on soil moisture than temperature. Rh was variable and did not respond strongly to temperature. In shrubs Rh was predicted better by VWC than

15 temperature, but in invaded areas neither temperature nor VWC fit the Rh data well (Table S3).

\subsection{Autotrophic respiration depends on soil temperature, moisture and time of year}

Ra had a similar seasonal pattern as $\mathrm{Rt}$ and $\mathrm{Rh}$ although the seasonal contribution 20 of Ra varied substantially throughout the season and with vegetation type (Fig. 2c). When Ra was considered based on soil temperature and moisture conditions, with the additional factor of time, some interesting patterns emerged (Fig. 6). Generally Ra increased with temperature when VWC $>10 \%$ and declined when $\mathrm{VWC}<10 \%$; like $\mathrm{Rt}$ and $\mathrm{Rh}$. In invaded areas $\mathrm{Ra}$ increased and was tightly correlated with temperature $25 \quad\left(r^{2}=0.81\right)$, as long as VWC $>10 \%$ (Fig. 6b). In shrubs when VWC $>10 \%$ Ra was not as tightly correlated with temperature $\left(r^{2}=0.57\right)$. Ra only increased in spring months

$$
6349
$$

(Fig. 6a) while the winter months Nov, Dec and Jan formed an outlier group below the line. During these months $\mathrm{Ra}$ was not correlated with temperature indicating that $\mathrm{Ra}$ activity under native shrubs was low and did not change much from day to day. Ra, like $\mathrm{Rt}$ had a lower temperature threshold than invaded areas (Fig. 6a).

At $\mathrm{VWC}<10 \%$ Ra correlated poorly with temperature in invaded plots and not at all under shrubs (Fig. 6). Ra is likely to be more sensitive to VWC. The shrubs are preparing for summer dormancy and therefore unlikely to respond to seasonal fluctuations in temperature.

\subsection{Diurnal cycles highlight phenological differences between invasives and} 10 shrubs

Soil temperature, light and plant activity all vary diurnally, but their effects can be masked by strong seasonal trends. Soil moisture, phenology and microbial community composition do not have strong diurnal patterns; therefore diurnal data helps to isolate seasonal respiration trends from the effects of temperature, light or photosynthate

15 transport on respiration patterns. Diurnal soil respiration was investigated in three representative parts of the season; spring (11-21 February 2010), late spring (1-10 May 2010) and summer (1-10 June 2010) to capture seasonal windows in which phenology and moisture differ distinctly. Average $\mathrm{Ra}$ and $\mathrm{Rh}$ were calculated in invaded and shrub areas for each time point within the three 10 day periods.

20 In spring the overall magnitude and pattern of diurnal $\mathrm{Ra}$ and $\mathrm{Rh}$ did not differ significantly from each other or between vegetation types (ANOVA vegetation effect, $p=0.238$; root effect $p=0.46$; Fig. $7 \mathrm{a}, \mathrm{b}$; Table 3 ). In late spring, respiration rates increased. Invasive $\mathrm{Ra}$ and $\mathrm{Rh}$ were significantly higher than in shrubs (ANOVA, vegetation effect $p<0.01$; root effect $p<0.01$; Fig. 7c and d; Table 3). Surprisingly, in

25 summer, invaded areas had a diurnal Ra signal and a slight diurnal Rh signal, despite maximum temperatures reaching $49^{\circ} \mathrm{C}$. Shrubs showed no diurnal variation, $\mathrm{Ra}$ in shrubs was very close to $\mathrm{Rh}$ and interestingly shrub $\mathrm{Rh}$ showed a slight midday 
depression (ANOVA, vegetation effect, $p<0.05$, treatment effect, $p<0.01$; Fig. 7e and f; Table 3).

Daily average data indicated a seasonal temperature threshold between $15-20^{\circ} \mathrm{C}$ (Fig. 5) but from the diurnal data it is clear that respiration continued even with tem5 peratures as high as $35^{\circ} \mathrm{C}$ for shrubs and $46^{\circ} \mathrm{C}$ for invasives. It was not uncommon for temperatures in this system to differ by as much as $20^{\circ} \mathrm{C}$ within $24 \mathrm{~h}$. Therefore the seasonal temperature threshold, based on daily averages does not really indicate maximum temperature sensitivity but rather a combination of phenological and soil moisture changes. The fundamental differences in the way that respiration rates de-

10 clined between invaded areas and shrubs, on a seasonal and diurnal basis, supports the role of phenology and differences in microbial physiology as additional controlling variables in respiration.

\section{Discussion}

Invasion increased cumulative respiration rates by $40 \%$ compared to shrubs. This in15 crease was due to higher $\mathrm{Ra}$ and altered temperature sensitivity in invaded areas, best explained by a combination of altered root respiration rates, differences in microbial stress tolerance, changes in root exudates, and shifted phenology of the invasives resulting in a longer "respiration season". Soil respiration was strongly dependent on seasonal soil moisture and temperature changes, consistent with other semi-arid systems

20 (Noy-Meir, 1973; Neilson, 1995; Smith and Knapp, 2001; Austin et al., 2004; Huxman et al., 2004). Rt and Rh increased with temperature when soils were wet and decreased as soils became progressively drier and hotter. The negative response is particularly interesting because the temperature threshold ranged from $15-20^{\circ} \mathrm{C}$, well below expected thresholds of biological activity. However, the temperature threshold overlapped

25 with a soil moisture threshold around $10 \%$ and the temperature response of invasives and shrubs had a strong temporal component, similar to findings in $\mathrm{Xu}$ and Baldocchi (2004). Our cumulative estimates are similar to those of Xu and Baldocchi (2004) but 6351

lower than Tang and Baldocchi (2005), two studies in annual invasive grasslands in northern California. Tang and Baldocchi (2005) based their estimates on monthly soil respiration measurements, missing much of the dynamic Rt pattern. This highlights the importance of high frequency measurements which capture the ephemeral contribution 5 of rain events to soil respiration (Austin et al., 2004; Carbone and Vargas, 2008). Our results support the mounting evidence that respiration dynamics are driven by complex interactions between soil temperature, moisture and plant phenology (Davidson and Janssens, 2006; Davidson and Holbrook, 2009; Vargas et al., 2010).

\subsection{Microclimate effects on soil respiration}

10 Energy partitioning in semi-arid ecosystems is heterogeneous (Domingo et al., 2000; Baldocchi et al., 2004; Scott et al., 2006). Lower albedo and greater soil heat flux increases soil temperatures when grasses invade shrubland (Prater and DeLucia, 2006). At our site soil moisture did not differ with vegetation type, despite higher temperatures in invaded areas, possibly because evaporation, rather than transpiration, con-

15 trols shallow soil moisture (Kurc and Small, 2007). Hotter microclimates have been found to increase respiration rates and cause a more rapid temperature response in other semi-arid ecosystems (Smith and Johnson, 2004). The maintenance of a diurnal $\mathrm{Rt}$ and $\mathrm{Rh}$ signal indicates that invaded areas were able to tolerate higher temperatures than shrubs. This is supported by lab experiments (Hale and Lipson, unpublished). In

20 contrast, other studies have shown that soil respiration rates are not necessarily higher when temperatures increase (Luo et al., 2001). This contradiction indicates that it is difficult to predict respiration rates from temperature responses alone. Soil $\mathrm{C}$ dynamics and plant-microbe interactions play an important role in the respiration response to temperature and moisture. Positive feedback between the stress tolerant, invasive 25 plant community can select for a stress tolerant microbial community (Lau and Lennon, 2012). Previous work has shown that invasion in CSS changes the microbial community (Siguenza et al., 2006; El Souki, 2007) and increases the fungi: bacteria ratio (Wolkovich et al., 2010) and warmer microclimates select for fungi (Zhang et al., 2005). 
Annual grass invasion changes the dynamics of microbial SOM decomposition (Waldrop and Firestone, 2004) and $C$. solstitialis, a dominant invasive at this site, is closely related to C. maculosa which alters root exudates and microbial community composition (Callaway and Ridenour, 2004). Although complete plant removal can have detri-

5 mental effects on microbial communities (Wardle et al., 1999), the remarkable consistency in the Rh patterns between the two years indicates that invasion left a legacy of altered microbial community functional traits.

\subsection{The effect of carbon quality and allocation on soil respiration}

The Rh contribution to total cumulative respiration was around $40 \%$ in invaded areas 10 and $60 \%$ under shrubs. This contribution varied seasonally, but primarily due to large seasonal fluctuations in $\mathrm{Ra}$ rather than in $\mathrm{Rh}$, consistent with other semi-arid ecosystems (Carbone et al., 2008). Over the course of a growing season large quantities of labile, easily respired soil $\mathrm{C}$ come from root exudate production which is tightly coupled to photosynthesis (Hogberg and Read, 2006). Annual, rapidly growing plants are

15 capable of high photosynthetic rates (Aerts and Chapin, 2000) and allocate more respiration to their roots (Carbone and Trumbore, 2007) than slower growing plants. In wet soils, tight correlations between temperature and Rt indicate a shorter delay between $C$ fixation, root exudation and root respiration in invaded areas compared to shrubs (Yuste et al., 2004; Vargas and Allen, 2008; Kuzyakov and Gavrichkova, 2010; Ward 20 et al., 2009). In this study, Rh contributions tended to be highest when plant activity was limited by water availability and during early season rain events. In semi-arid systems the first rain event stimulates microbial activity and provides essential nutrients for the entire ecosystem (Birch, 1958; Austin et al., 2004; Huxman et al., 2004). It is important to note that the large $\mathrm{CO}_{2}$ pulse we observed in September 2010 occurred 25 prior to root growth. Yet, soil respiration was higher in Rt compared to Rh treatments. $\mathrm{CO}_{2}$ respired from the $\mathrm{Rh}$ treatment was low because it is derived from $\mathrm{C}$ occluded in bulk soil (Miller et al., 2005; Xiang et al., 2008; Borken and Matzner, 2009) while microbes present in the Rt treatment are supplemented by plant litter and soil $\mathrm{C}$ from the 6353

previous growing season (Xu and Baldocchi, 2004). Accumulation and slow decomposition of annual grass litter in CSS has been linked to increased soil C (Wolkovich et al., 2010), however we did not observe differences in SOM, labile or recalcitrant soil $C$ between invasives and shrubs (data not shown). This could be because the mixture

5 of invasive annual grasses and forbs did not produce a thick thatch layer at our site, or our measures of soil $\mathrm{C}$ were not sensitive enough to detect differences (Gill and Burke, 1999).

Because our Rh treatments exclude all root inputs they provide insight into the residence time of SOM pools, an important component of ecosystem C storage (Gaudinski et al., 2000). Root exudates turn over on the order of days (Carbone and Trumbore, 2007; Bahn et al., 2009) and certainly within a year (Gaudinski et al., 2000). We trenched our plots immediately following the first rainfall event in December 2009 and began measuring respiration in February 2010, after a brief acclimation period (Hanson et al., 2000). In our system root biomass dynamics are tightly coupled to plant growth and root biomass at the end of the summer is extremely low. Installing root exclusion cores before any plant growth has occurred excludes the majority of root biomass, reducing concerns about root decomposition contributing to $\mathrm{Rh}$ (Epron et al., 1999). Rh did not differ appreciably between the two years, neither in terms of cumulative respiration nor in seasonal patterns. Thus, we conclude that the turnover time for the $\mathrm{C}$ 20 pool in root exclusion treatments is greater than two years. From the beginning of our experiment, after a one month acclimation of root exclusion cores, Rh was $50 \%$ of Rt. This dramatic attenuation strongly supports the conclusion that respiration of recently fixed photosynthate is a large component of soil respiration in CSS. Our estimates of $\mathrm{Rh}$ almost certainly underestimate heterotrophic activity because up to $60 \%$ of rhizo-

25 sphere respiration is thought to come from heterotrophs directly associated with roots and stimulated by root exudates (Kuzyakov, 2002b). Priming, a process in which labile substrates enhance the decomposition of recalcitrant substrates, is diminished in the absence of root inputs which could result in underestimates of recalcitrant $\mathrm{C}$ decomposition (Kuzyakov, 2002a; Fontaine et al., 2007). Our patterns of Ra and Rh contribution 
are however consistent with trenching experiments (Tang et al., 2005) and ${ }^{14} \mathrm{C}$ isotope studies (Carbone et al., 2008; Carbone et al., 2011) in other semi-arid communities.

\subsection{Impacts of invasion on soil C dynamics in CSS}

The effect of invasion on soil respiration is poorly understood and the impact on re5 gional and global C cycling is almost entirely unknown (Metcalfe et al., 2011). The success of invasive species is often linked to changing climate conditions (Vitousek et al., 1996); therefore it is important that the role of new community assemblages is considered simultaneously with responses to future climate conditions (Chapin et al., 2009). Links between plant community composition, phenology and soil respiration are

10 typically ignored in $\mathrm{C}$ models but will become increasingly important if plant phenology and climate conditions shift (Xu and Baldocchi, 2004; Vargas et al., 2011). Phenology is particularly important in extremely water limited systems and in some cases the timing of rainfall, rather than the total amount of rainfall, affects whether semi-arid areas are a C source or sink (Xu and Baldocchi, 2004; Aanderud et al., 2010).

15 Under current conditions phenology of the plant community overlaps with suitable soil temperature, and moisture. CSS is drought deciduous and has its main growing season from February to May (Gray and Schlesinger, 1981; Schoenherr, 1992). In contrast invasive annual grasses and forbs germinate with the first large rain event of the season (Bartolome, 1979; Enloe et al., 2004; Eviner and Firestone, 2007). Rt,

20 Ra and $\mathrm{Rh}$ in invaded areas were constrained by low temperatures. Therefore, if winter temperatures were to increase or if the rainy season starts earlier, it is likely that soil respiration will increase more in invaded areas than under shrubs. If the invasive community consisted only of annual grasses we would expect respiration to decline earlier than in the perennial shrubs. But the presence of late season forbs in the in-

25 vaded areas altered the end of season respiration decline. Even when soils were dry and reached maximum temperatures of $49^{\circ} \mathrm{C}$ the diurnal pattern was maintained, indicating continued photosynthesis and respiration (Liu et al., 2006). The dominant forb is

6355

C. solstitialis which remains active, despite high water stress (Gerlach and Rice, 2003; Hill and Germino, 2005) because it is able to access deeper water supplies (Spencer et al., 2011). C. maculosa a related, highly aggressive invasive, is able to tolerate high water stress because it has multiple types of photosynthetic tissue (Hill and Germino, 5 2005) allowing it to gain C late into the summer (Hill et al., 2006). In contrast the shrubs are constrained by phenological canalization which limits their ability to respond to transient, favorable periods (Snyder et al., 2004). At the end of the season, when soils are dry the shrubs enter dormancy as temperatures increase. In contrast invasives have a "respire 'till you die" approach.

10 If, in the future, the temporal patterns of temperature and precipitation patterns change, effects on the phenologically constrained native community could be detrimental. Because shrubs grow slowly, plant productivity, ecosystem respiration and annual precipitation patterns may be decoupled between years. In contrast a large annual component may result in tighter coupling between productivity and respiration. There-

15 fore the response of this system to changes in the timing of precipitation events is likely to depend on the invasive community. For instance if, as our study indicates, Rh is not affected by invasion, and higher invasive $\mathrm{Ra}$ is offset by photosynthesis then a rainfall year which increases annual growth may increase $C$ storage for that year. However there is evidence that increased annual grass Rt is not offset by greater productivity

20 (Koteen et al., 2011) and if large amounts of annual litter accumulate in the system in higher rainfall years then productivity and decomposition could become decoupled and alter ecosystem C storage dynamics (Xu and Baldocchi, 2004; Austin and Vivanco, 2006).

Currently our ability to predict soil respiration dynamics relies on moisture and tem25 perature. This creates severe limitations when we attempt to understand soil respiration and ecosystem $\mathrm{C}$ storage under future climate scenarios (Subke et al., 2012). Plant phenologies have evolved in order for plant growth to overlap with suitable environmental conditions, but climate change disrupts this synchrony. Improving our mechanistic understanding of how phenology influences the response of soil respiration to moisture 
and temperature changes will allow us to assess how changing plant community composition might respond to expected environmental conditions (Metcalfe et al., 2011; Kuzyakov and Gavrichkova, 2010; Chapin et al., 2009; Reich, 2010; Vargas et al., 2011).

\section{Supplementary material related to this article is available online at: http://www.biogeosciences-discuss.net/10/6335/2013/ bgd-10-6335-2013-supplement.pdf.}

Acknowledgements. Walt Oechel for lending Licor 8100 equipment, Joe Verfaille and Pablo Bryant for field support, Cove Sturtevant and Hiroki lkawa for Matlab assistance,

10 Doug Deutschman for statistical consultation, Chun-Ta Lai for feedback and Lipson Lab for constant, invaluable support. The Joint Doctoral Program in Ecology for funding.

\section{References}

Aanderud, Z. T., Richards, J. H., Svejcar, T., and James, J. J.: A shift in seasonal rainfall reduces soil organic carbon storage in a cold desert, Ecosystems, 13, 673-682, doi:10.1007/s1002115 010-9346-1, 2010.

Aanderud, Z. T., Schoolmaster, D. R., and Lennon, J. T.: Plants mediate the sensitivity of soil respiration to rainfall variability, Ecosystems, 14, 156-167, doi:10.1007/s10021-010-9401-y, 2011.

Aerts, R. and Chapin, F. S.: The mineral nutrition of wild plants revisited: a re-evaluation of 20 processes and patterns, Academic Press, 2000.

Austin, A. T., Yahdjian, L., Stark, J. M., Belnap, J., Porporato, A., Norton, U., Ravetta, D. A., and Schaeffer, S. M.: Water pulses and biogeochemical cycles in arid and semiarid ecosystems, Oecologia, 141, 221-235, doi:10.1007/s00442-004-1519-1, 2004.

Austin, A. T. and Vivanco, L.: Plant litter decomposition in a semi-arid ecosystem controlled by photodegradation, Nature, 442, 555-558, doi:10.1038/nature05038, 2006.

\section{7}

Bahn, M., Schmitt, M., Siegwolf, R., Richter, A., and Bruggemann, N.: Does photosynthesis affect grassland soil-respired $\mathrm{CO}_{2}$ and its carbon isotope composition on a diurnal timescale?, New Phytol., 182, 451-460, doi:10.1111/j.1469-8137.2008.02755.x, 2009.

Baldocchi, D. D., Xu, L. K., and Kiang, N.: How plant functional-type, weather, seasonal drought, and soil physical properties alter water and energy fluxes of an oak-grass savanna and an annual grassland, Agr. Forest Meteorol., 123, 13-39, doi:10.1016/j.agrformet.2003.11.006, 2004.

Bartolome, J. W.: Germination and seedling establishment in California annual grassland, J. Ecol., 67, 273-281, doi:10.2307/2259350, 1979.

10 Birch, H. F.: The effect of soil drying on humus decomposition and nitrogen availability, Plant Soil, 10, 9-31, 1958.

Bond-Lamberty, B. and Thomson, A.: Temperature-associated increases in the global soil respiration record, Nature, 464, 579-582, doi:10.1038/nature08930, 2010a.

Bond-Lamberty, B. and Thomson, A.: A global database of soil respiration data, Biogeosciences, 7, 1915-1926, doi:10.5194/bg-7-1915-2010, 2010b.

Boone, R. D., Nadelhoffer, K. J., Canary, J. D., and Kaye, J. P.: Roots exert a strong influence on the temperature sensitivity of soil respiration, Nature, 396, 570-572, doi:10.1038/25119, 1998.

Borken, W. and Matzner, E.: Reappraisal of drying and wetting effects on C and N mineralization and fluxes in soils, Global Change Biol., 15, 808-824, doi:10.1111/j.13652486.2008.01681.x, 2009.

Briggs, J. M., Knapp, A. K., Blair, J. M., Heisler, J. L., Hoch, G. A., Lett, M. S., and McCarron, J. K.: An ecosystem in transition, causes and consequences of the conversion of mesic grassland to shrubland, Bioscience, 55, 243-254, 2005.

25 Callaway, R. M. and Ridenour, W. M.: Novel weapons: invasive success and the evolution of increased competitive ability, Front. Ecol. Environ., 2, 436-443, doi:10.1890/15409295(2004)002[0436:nwisat]2.co;2, 2004.

Carbone, M. S. and Trumbore, S. E.: Contribution of new photosynthetic assimilates to respiration by perennial grasses and shrubs: residence times and allocation patterns, New Phytol. 176, 124-135, doi:10.1111/j.1469-8137.2007.02153.x, 2007.

Carbone, M. S. and Vargas, R.: Automated soil respiration measurements: new information, opportunities and challenges, New Phytol., 177, 295-297, 2008. 
Carbone, M. S., Winston, G. C., and Trumbore, S. E.: Soil respiration in perennial grass and shrub ecosystems: Linking environmental controls with plant and microbial sources on seasonal and diel timescales, J. Geophys. Res.-Biogeo., 113, G02022, doi:10.1029/2007jg000611, 2008.

5 Carbone, M. S., Still, C. J., Ambrose, A. R., Dawson, T. E., Williams, A. P., Boot, C. M., Schaeffer, S. M., and Schimel, J. P.: Seasonal and episodic moisture controls on plant and microbial contributions to soil respiration, Oecologia, 167, 265-278, doi:10.1007/s00442-011-1975-3, 2011.

Chapin, F. S., McFarland, J., McGuire, A. D., Euskirchen, E. S., Ruess, R. W., and Kielland, K.: The changing global carbon cycle: linking plant-soil carbon dynamics to global consequences, J. Ecol., 97, 840-850, doi:10.1111/j.1365-2745.2009.01529.x, 2009.

D'Antonio, C. M. and Vitousek, P. M.: Biological invasions by exotic grasses, the grass fire cycle, and global change, Ann. Rev. Ecol. Systemat., 23, 63-87, 1992.

Davidson, E. and Holbrook, N.: Phenology of Ecosystem Processes, Springer, 2009.

15 Davidson, E. A. and Janssens, I. A.: Temperature sensitivity of soil carbon decomposition and feedbacks to climate change, Nature, 440, 165-173, doi:10.1038/nature04514, 2006.

Davidson, E. A., Belk, E., and Boone, R. D.: Soil water content and temperature as independent or confounded factors controlling soil respiration in a temperate mixed hardwood forest, Global Change Biol., 4, 217-227, doi:10.1046/j.1365-2486.1998.00128.x, 1998.

20 Davidson, E. A., Janssens, I. A., and Luo, Y. Q.: On the variability of respiration in terrestrial ecosystems: moving beyond Q(10), Global Change Biol., 12, 154-164, doi:10.1111/j.13652486.2005.01065.x, 2006.

Davidson, E. A., Samanta, S., Caramori, S. S., and Savage, K.: The Dual Arrhenius and Michaelis-Menten kinetics model for decomposition of soil organic matter at hourly to seasonal time scales, Global Change Biol., 18, 371-384, doi:10.1111/j.13652486.2011.02546.x, 2012.

Domingo, F., Villagarcia, L., Brenner, A. J., and Puigdefabregas, J.: Measuring and modelling the radiation balance of a heterogeneous shrubland, Plant Cell Environ., 23, 27-38, doi:10.1046/j.1365-3040.2000.00532.x, 2000.

30 El Souki, F.: Effects of nitrogen additions and exotic grasses on nitrogen cycling and microbial communities in coastal sage scrub soil, MS Thesis, San Diego State University, 2007.

6359

Enloe, S. F., DiTomaso, J. M., Orloff, S. B., and Drake, D. J.: Soil water dynamics differ among rangeland plant communities dominated by yellow starthistle (Centaurea solstitialis), annual grasses, or perennial grasses, Weed Sci., 52, 929-935, doi:10.1614/ws-03-156r, 2004.

Epron, D., Farque, L., Lucot, E., and Badot, P. M.: Soil $\mathrm{CO}_{2}$ efflux in a beech forest: the contribution of root respiration, Ann. Forest Sci., 56, 289-295, doi:10.1051/forest:19990403, 1999.

Eviner, V. T. and Firestone, M. K.: Mechanisms determining patterns of nutrient dynamics, in: California Grasslands: Ecology and Management, edited by: Stromberg, M. R., Corbin, J. D., and D'Antonio, C. M., University of California Press, 94-106, 2007.

Fontaine, S., Barot, S., Barre, P., Bdioui, N., Mary, B., and Rumpel, C.: Stability of or-

10 ganic carbon in deep soil layers controlled by fresh carbon supply, Nature, 450, 277-280, doi:10.1038/nature06275, 2007.

Gaudinski, J. B., Trumbore, S. E., Davidson, E. A., and Zheng, S. H.: Soil carbon cycling in a temperate forest: radiocarbon-based estimates of residence times, sequestration rates and partitioning of fluxes, Biogeochemistry, 51, 33-69, doi:10.1023/a:1006301010014, 2000.

15 Gerlach, J. D. and Rice, K. J.: Testing life history correlates of invasiveness using congeneric plant species, Ecol. Appl., 13, 167-179, doi:10.1890/10510761(2003)013[0167:tlhcoi]2.co;2, 2003.

Gill, R. A. and Burke, I. C.: Ecosystem consequences of plant life form changes at three sites in the semiarid United States, Oecologia, 121, 551-563, 1999.

20 Goodale, C. L. and Davidson, E. A.: Carbon cycle: uncertain sinks in the shrubs, Nature, 418, 593-594, doi:10.1038/418593a, 2002.

Graf, A., Weihermuller, L., Huisman, J. A., Herbst, M., and Vereecken, H.: Comment on "Global Convergence in the Temperature Sensitivity of Respiration at Ecosystem Level", Science, 331, 1265, doi:10.1126/science.1196948, 2011.

25 Gray, J. T. and Schlesinger, W. H.: Biomass, production, and litterfall in the coastal sage scrub of southern-California, Am. J. Bot., 68, 24-33, 1981.

Hanson, P. J., Edwards, N. T., Garten, C. T., and Andrews, J. A.: Separating root and soil microbial contributions to soil respiration: a review of methods and observations, Biogeochemistry, 48, 115-146, doi:10.1023/a:1006244819642, 2000.

30 Hill, J. P. and Germino, M. J.: Coordinated variation in ecophysiological properties among life stages and tissue types in an invasive perennial forb of semiarid shrub steppe, Can. J. Bot., 83, 1488-1495, doi:10.1139/b05-116, 2005. 
Hill, J. P., Germino, M. J., Wraith, J. M., Olson, B. E., and Swan, M. B.: Advantages in water relations contribute to greater photosynthesis in Centaurea maculosa compared with established grasses, Int. J. Plant Sci., 167, 269-277, doi:10.1086/499505, 2006.

Hogberg, P. and Read, D. J.: Towards a more plant physiological perspective on soil ecology, Trends Ecol. Evol., 21, 548-554, doi:10.1016/j.tree.2006.06.004, 2006.

Huxman, T. E., Snyder, K. A., Tissue, D., Leffler, A. J., Ogle, K., Pockman, W. T., Sandquist, D. R., Potts, D. L., and Schwinning, S.: Precipitation pulses and carbon fluxes in semiarid and arid ecosystems, Oecologia, 141, 254-268, doi:10.1007/s00442-004-16824, 2004.

10 Jackson, R. B., Schenk, H. J., Jobbagy, E. G., Canadell, J., Colello, G. D., Dickinson, R. E., Field, C. B., Friedlingstein, P., Heimann, M., Hibbard, K., Kicklighter, D. W., Kleidon, A., Neilson, R. P., Parton, W. J., Sala, O. E., and Sykes, M. T.: Belowground consequences of vegetation change and their treatment in models, Ecol. Appl., 10, 470-483, 2000.

Koteen, L. E., Baldocchi, D. D., and Harte, J.: Invasion of non-native grasses causes

15 a drop in soil carbon storage in California grasslands, Environ. Res. Lett., 6, 044001, doi:10.1088/1748-9326/6/4/044001, 2011.

Kurc, S. A. and Small, E. E.: Soil moisture variations and ecosystem-scale fluxes of water and carbon in semiarid grassland and shrubland, Water Resour. Res., 43, W064116, doi:10.1029/2006wr005011, 2007.

20 Kuzyakov, Y.: Review: factors affecting rhizosphere priming effects, J. Plant Nutr. Soil Sci., 165, 382-396, 2002a.

Kuzyakov, Y.: Separating microbial respiration of exudates from root respiration in non-sterile soils: a comparison of four methods, Soil Biol. Biochem., 34, 1621-1631, doi:10.1016/s00380717(02)00146-3, 2002b.

25 Kuzyakov, Y. and Gavrichkova, O.: REVIEW: time lag between photosynthesis and carbon dioxide efflux from soil: a review of mechanisms and controls, Global Change Biol., 16, 33863406, doi:10.1111/j.1365-2486.2010.02179.x, 2010.

Lau, J. A. and Lennon, J. T.: Rapid responses of soil microorganisms improve plant fitness in novel environments, Proc. Natl. Acad. Sci. USA, 109, 14058-14062, doi:10.1073/pnas.1202319109, 2012.

Lellei-Kovacs, E., Kovacs-Lang, E., Botta-Dukat, Z., Kalapos, T., Emmett, B., and Beier, C.: Thresholds and interactive effects of soil moisture on the temperature response of soil respiration, Eur. J. Soil Biol., 47, 247-255, doi:10.1016/j.ejsobi.2011.05.004, 2011.

6361

Liu, Q., Edwards, N. T., Post, W. M., Gu, L., Ledford, J., and Lenhart, S.: Temperatureindependent diel variation in soil respiration observed from a temperate deciduous forest, Global Change Biol., 12, 2136-2145, doi:10.1111/j.1365-2486.2006.01245.x, 2006.

Luo, Y. Q., Wan, S. Q., Hui, D. F., and Wallace, L. L.: Acclimatization of soil respiration to warming in a tall grass prairie, Nature, 413, 622-625, doi:10.1038/35098065, 2001.

Mahecha, M. D., Reichstein, M., Carvalhais, N., Lasslop, G., Lange, H., Seneviratne, S. I., Vargas, R., Ammann, C., Arain, M. A., Cescatti, A., Janssens, I. A., Migliavacca, M., Montagnani, L., and Richardson, A. D.: Response to Comment on "Global Convergence in the Temperature Sensitivity of Respiration at Ecosystem Level", Science, 331, 1265, doi:10.1126/science.1197033, 2011.

Metcalfe, D. B., Fisher, R. A., and Wardle, D. A.: Plant communities as drivers of soil respiration: pathways, mechanisms, and significance for global change, Biogeosciences, 8, 2047-2061, doi:10.5194/bg-8-2047-2011, 2011.

Miller, A. E., Schimel, J. P., Meixner, T., Sickman, J. O., and Melack, J. M.: Episodic rewetting

15 enhances carbon and nitrogen release from chaparral soils, Soil Biol. Biochem., 37, 21952204, doi:10.1016/j.soilbio.2005.03.021, 2005.

Neilson, R. P.: A model for predicting continental-scale vegetation distribution and waterbalance, Ecol. Appl., 5, 362-385, doi:10.2307/1942028, 1995.

Noy-Meir, I.: Desert ecosystems, environment and producers, Ann. Rev. Ecol. Systemat., 4, 25-51, 1973.

Prater, M. R. and DeLucia, E. H.: Non-native grasses alter evapotranspiration and energy balance in Great Basin sagebrush communities, Agr. Forest Meteorol., 139, 154-163, doi:10.1016/j.agrformet.2006.08.014, 2006.

Raich, J. W. and Tufekcioglu, A.: Vegetation and soil respiration: correlations and controls, Biogeochemistry, 48, 71-90, doi:10.1023/a:1006112000616, 2000.

Reich, P. B.: The carbon dioxide exchange, Science, 329, 774-775, doi:10.1126/science.1194353, 2010.

Savage, K., Davidson, E. A., and Richardson, A. D.: A conceptual and practical approach to data quality and analysis procedures for high-frequency soil respiration measurements, Funct. Ecol., 22, 1000-1007, doi:10.1111/j.1365-2435.2008.01414.x, 2008.

Savage, K., Davidson, E. A., and Tang, J.: Diel patterns of autotrophic and heterotrophic respiration among phenological stages, Global Change Biol., 1151-1159, doi:10.1111/gcb.12108, 2013. 
Schoenherr, A. A.: A Natural History of California, University of California Press, 1992.

Scott, R. L., Huxman, T. E., Cable, W. L., and Emmerich, W. E.: Partitioning of evapotranspiration and its relation to carbon dioxide exchange in a Chihuahuan Desert shrubland, Hydrolog. Process., 20, 3227-3243, doi:10.1002/hyp.6329, 2006.

5 Siguenza, C., Crowley, D. E., and Allen, E. B.: Soil microorganisms of a native shrub and exotic grasses along a nitrogen deposition gradient in southern California, Appl. Soil Ecol., 32, 13-26, doi:10.1016/j.apsoil.2005.02.015, 2006.

Smith, D. L. and Johnson, L.: Vegetation-mediated changes in microclimate reduce soil respiration as woodlands expand into grasslands, Ecology, 85, 3348-3361, doi:10.1890/03-0576, 2004.

Smith, M. D. and Knapp, A. K.: Physiological and morphological traits of exotic, invasive exotic, and native plant species in tallgrass prairie, Int. J. Plant Sci., 162, 785-792, doi:10.1086/320774, 2001.

Snyder, K. A., Donovan, L. A., James, J. J., Tiller, R. L., and Richards, J. H.: Extensive summer

15 water pulses do not necessarily lead to canopy growth of Great Basin and northern Mojave Desert shrubs, Oecologia, 141, 325-334, doi:10.1007/s00442-003-1403-4, 2004.

Spencer, D., Enloe, S., Liow, P. S., Ksander, G., and Carruthers, R.: Does Superior Competitive Ability Explain Yellow Starthistle's (Centaurea solstitialis) Successful Invasion of Annual Grasslands in California?, Invasive Plant Science and Management, 4, 284-295, doi:10.1614/ipsm-d-10-00092.1, 2011.

Subke, J. A., Carbone, M. S., Khomik, M., Stoy, P., and Bahn, M.: Preface "Biotic interactions and biogeochemical processes in the soil environment", Biogeosciences, 9, 1823-1825, doi:10.5194/bg-9-1823-2012, 2012.

Tang, J. W. and Baldocchi, D. D.: Spatial-temporal variation in soil respiration in an oak-grass

25 savanna ecosystem in California and its partitioning into autotrophic and heterotrophic components, Biogeochemistry, 73, 183-207, doi:10.1007/s10533-004-5889-6, 2005.

Tang, J. W., Misson, L., Gershenson, A., Cheng, W. X., and Goldstein, A. H.: Continuous measurements of soil respiration with and without roots in a ponderosa pine plantation in the Sierra Nevada Mountains, Agr. Forest Meteorol., 132, 212-227, doi:10.1016/j.agrformet.2005.07.011, 2005.

Van Auken, O. W.: Shrub invasions of North American semiarid grasslands, Ann. Rev. Ecol. Systemat., 31, 197-215, 2000.

6363

Vargas, R. and Allen, M. F.: Environmental controls and the influence of vegetation type, fine roots and rhizomorphs on diel and seasonal variation in soil respiration, New Phytol., 179, 460-471, doi:10.1111/j.1469-8137.2008.02481.x, 2008.

Vargas, R., Baldocchi, D. D., Allen, M. F., Bahn, M., Black, T. A., Collins, S. L., Yuste, J. C., Hirano, T., Jassal, R. S., Pumpanen, J., and Tang, J. W.: Looking deeper into the soil: biophysical controls and seasonal lags of soil $\mathrm{CO}_{2}$ production and efflux, Ecol. Appl., 20, 1569-1582, doi:10.1890/09-0693.1, 2010.

Vargas, R., Carbone, M. S., Reichstein, M., and Baldocchi, D. D.: Frontiers and challenges in soil respiration research: from measurements to model-data integration, Biogeochemistry, 102, 1-13, doi:10.1007/s10533-010-9462-1, 2011.

Vitousek, P. M., Dantonio, C. M., Loope, L. L., and Westbrooks, R.: Biological invasions as global environmental change, Am. Sci., 84, 468-478, 1996.

Waldrop, M. P. and Firestone, M. K.: Microbial community utilization of recalcitrant and simple carbon compounds: impact of oak-woodland plant communities, Oecologia, 138, 275-284, doi:10.1007/s00442-003-1419-9, 2004.

Ward, S. E., Bardgett, R. D., McNamara, N. P., and Ostle, N. J.: Plant functional group identity influences short-term peatland ecosystem carbon flux: evidence from a plant removal experiment, Funct. Ecol., 23, 454-462, doi:10.1111/j.1365-2435.2008.01521.x, 2009.

Wardle, D. A., Bonner, K. I., Barker, G. M., Yeates, G. W., Nicholson, K. S., Bardgett, R. D., Watson, R. N., and Ghani, A.: Plant removals in perennial grassland: Vegetation dynamics, decomposers, soil biodiversity, and ecosystem properties, Ecol. Monogr., 69, 535-568, doi:10.1890/0012-9615(1999)069[0535:pripgv]2.co;2, 1999.

Wolkovich, E. M., Lipson, D. A., Virginia, R. A., Cottingham, K. L., and Bolger, D. T.: Grass invasion causes rapid increases in ecosystem carbon and nitrogen storage in a semiarid shrub-

25 land, Global Change Biol., 16, 1351-1365, doi:10.1111/j.1365-2486.2009.02001.x, 2010.

Xiang, S. R., Doyle, A., Holden, P. A., and Schimel, J. P.: Drying and rewetting effects on C and $\mathrm{N}$ mineralization and microbial activity in surface and subsurface California grassland soils, Soil Biol. Biochem., 40, 2281-2289, doi:10.1016/j.soilbio.2008.05.004, 2008.

$\mathrm{Xu}, \mathrm{L}$. K. and Baldocchi, D. D.: Seasonal variation in carbon dioxide exchange over

30 a Mediterranean annual grassland in California, Agr. Forest Meteorol., 123, 79-96, doi:10.1016/j.agrformet.2003.10.004, 2004. 
Xu, L. K., Baldocchi, D. D., and Tang, J. W.: How soil moisture, rain pulses, and growth alter the response of ecosystem respiration to temperature, Global Biogeochem. Cy., 18, doi:10.1029/2004gb002281, 2004.

Yuste, J. C., Janssens, I. A., Carrara, A., and Ceulemans, R.: Annual Q(10) of soil respiration 5 reflects plant phenological patterns as well as temperature sensitivity, Global Change Biol., 10, 161-169, doi:10.1111/j.1529-8817.2003.00727.x, 2004.

Zhang, W., Parker, K. M., Luo, Y., Wan, S., Wallace, L. L., and Hu, S.: Soil microbial responses to experimental warming and clipping in a tallgrass prairie, Global Change Biol., 11, 266277, doi:10.1111/j.1365-2486.2005.00902.x, 2005.

Table 1. Significance of vegetation (shrub or invaded) and root exclusion (Rt or Rh) effect on temperature and VWC. Each part of the season corresponds to that in Figs. 1 and 2.

\begin{tabular}{|c|c|c|c|c|c|c|c|}
\hline \multicolumn{8}{|c|}{ Effect of vegetation and treatment on microclimate } \\
\hline & & 2010 & & & 201 & & \\
\hline Period & Spring & Late Spring & Fall & Winter & Spring & Late Spring & Summer \\
\hline Date & 11 Feb-19 Apr & 20 Apr-1 Jul & 17 Sep-28 Oct & 5 Nov-11 Feb & 12 Feb-19 Apr & $20 \mathrm{Apr}-1 \mathrm{Jul}$ & 2 Jul-1 Aug \\
\hline Temperature & $\begin{array}{l}V_{\text {Veg }}^{\mathrm{b}} \\
\text { Root } \\
V \times R\end{array}$ & $\begin{array}{l}V{ }^{c} \\
\text { Root } \\
V \times R \\
\end{array}$ & $\begin{array}{l}V{ }^{c}{ }^{2} \\
\text { Root } \\
V \times R\end{array}$ & $\begin{array}{l}\text { Veg } \\
\operatorname{Root}^{\mathrm{a}} \\
V \times R^{\mathrm{a}}\end{array}$ & $\begin{array}{l}V^{V^{c}}{ }^{\mathrm{c}} \\
\operatorname{Root}^{\mathrm{a}} \\
V \times R^{\mathrm{a}}\end{array}$ & $\begin{array}{l}V{ }^{c} \\
\text { Root } \\
V \times R\end{array}$ & $\begin{array}{l}V{ }^{c}{ }^{c} \\
R o o t \\
V \times R\end{array}$ \\
\hline VWC & $\begin{array}{l}\text { Veg } \\
\text { Root } \\
V \times R\end{array}$ & $\begin{array}{l}\text { Veg } \\
\text { Root } \\
V \times R\end{array}$ & $\begin{array}{l}\text { Veg } \\
\text { Root } \\
V \times R\end{array}$ & \begin{tabular}{|l|} 
Veg \\
Root \\
$V \times R$
\end{tabular} & $\begin{array}{l}\text { Veg } \\
\text { Root } \\
V \times R\end{array}$ & $\begin{array}{l}\text { Veg } \\
\text { Root }^{\mathrm{a}} \\
V \times R\end{array}$ & $\begin{array}{l}\text { Veg } \\
\text { Root } \\
V \times R\end{array}$ \\
\hline
\end{tabular}


Table 2. Vegetation (shrub or invaded) and temperature effect on total (Rt) and heterotrophic (Rh) respiration at VWC $>15 \%, 10-15 \%$ and $<10 \%$. A significant veg $\times$ temp interaction shows that the temperature response differs between vegetation types.

\begin{tabular}{|c|c|c|}
\hline & Rt & $\mathrm{Rh}$ \\
\hline$V W C>15 \%$ & $\begin{array}{l}\text { veg } \\
\text { temperature }{ }^{c} \\
\text { veg } \times \text { temp }^{c}\end{array}$ & $\begin{array}{l}\text { veg }^{\mathrm{a}} \\
\text { temperature } \\
\text { veg } \times \text { temp }\end{array}$ \\
\hline VWC $10-15 \%$ & $\begin{array}{l}\text { veg } \\
\text { temperature } \\
\text { veg } \times \text { temp }^{\text {a }}\end{array}$ & $\begin{array}{l}\text { veg }^{c} \\
\text { temperature } \\
\text { veg } \times \text { temp }^{c}\end{array}$ \\
\hline VWC $<10 \%$ & 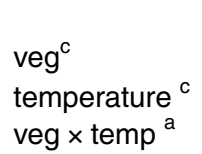 & $\begin{array}{l}\operatorname{veg}^{c} \\
\text { temperature } \\
\text { veg } \times \text { temp }\end{array}$ \\
\hline
\end{tabular}

6367

Table 3. Effect of vegetation (shrub or invaded) and root exclusion (Rt or Rh) on diurnal respiration in each part of the growing season; Spring, Late Spring and Summer.

\begin{tabular}{lll}
\hline Spring & Late Spring & Summer \\
\hline 11 Feb-21 Feb & 1 May-10 May & 1 Jun-10 Jun \\
\hline Veg & Veg $^{\mathrm{b}}$ & Veg $^{\mathrm{b}}$ \\
Roots & Roots $^{\mathrm{b}}$ & Roots $^{\mathrm{b}}$ \\
$V \times R$ & $V \times R$ & $V \times R$ \\
\hline${ }^{\mathrm{a}} p<0.05$, & \\
${ }^{\mathrm{b}} p<0.01$, & & \\
$\mathrm{c}^{\mathrm{c}} p<0.001$ based on RM ANOVA. & \\
& &
\end{tabular}




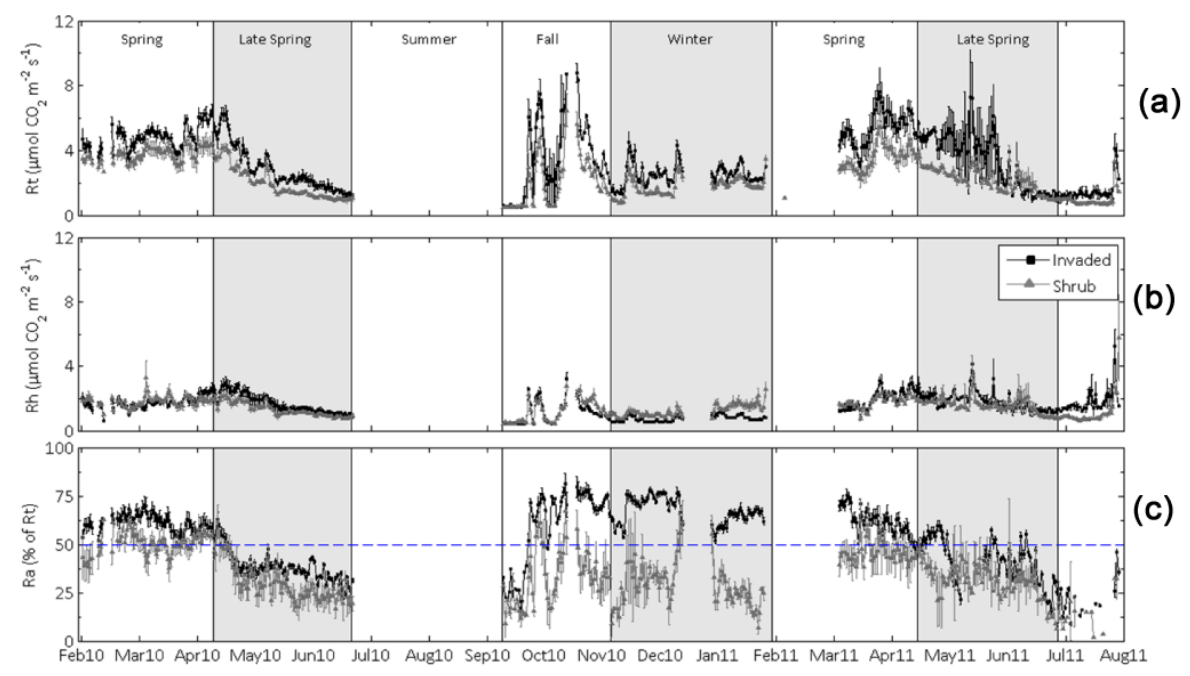

Fig. 1. Daily average total (Rt) (a), heterotrophic (Rh) (b) and autotrophic respiration (Ra) (c) for invaded (black line) and shrub (grey line) areas. Ra is calculated as percent of Rt (Ra $=($ Rt$\left.\mathrm{Rh}) / \mathrm{Rt})^{*} 100\right)$ ); the dashed line indicates the seasonal average Ra contribution at $50 \%$. Error bars show standard error based on four replicate chambers.

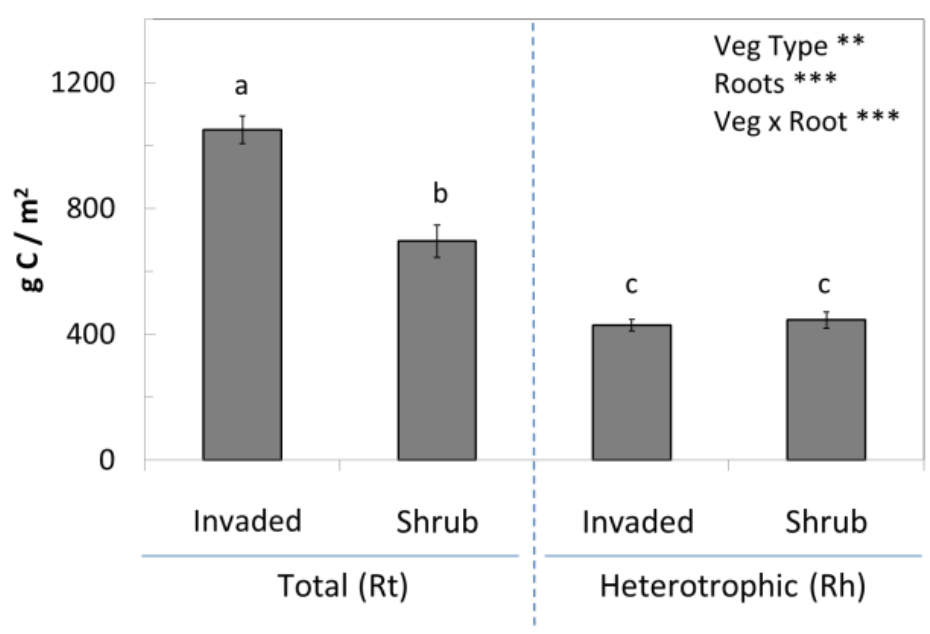

Fig. 2. Cumulative respiration for $\mathrm{Rt}$ and $\mathrm{Rh}$ in invaded and shrub areas for an entire growing season, September 2010-July 2011. Lower case letters indicate significant differences between vegetation (invaded and shrub) and root exclusion (Rh and Rt) based on Tukey's HSD. Error bars show standard error based on four replicate chambers. Asterisks indicate significance of each variable: ${ }^{* *} p<0.01,{ }^{* *} p<0.001$ based on ANOVA. 


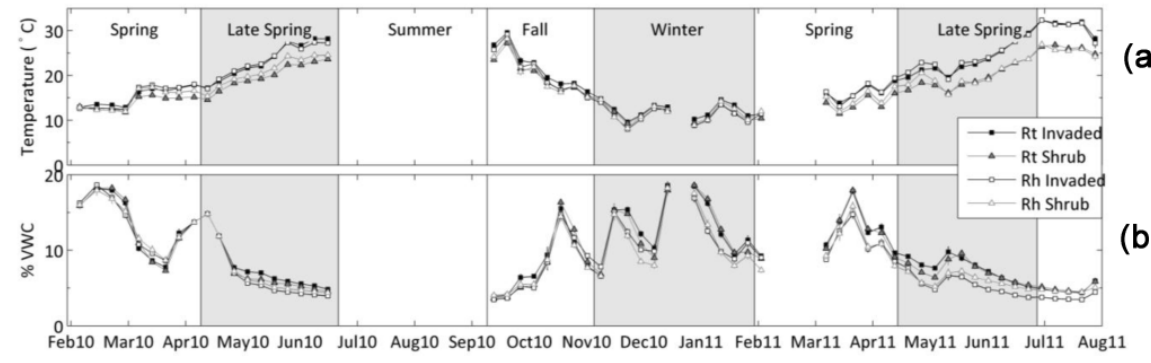

(a)

(b)

Fig. 3. Weekly average soil temperature $\left({ }^{\circ} \mathrm{C}\right)(\mathbf{a})$ and moisture (VWC) (b) for invaded (squares) and shrub (triangles), Rt (filled, dark) and Rh (open, light). Error bars show standard error based on four replicate chambers.

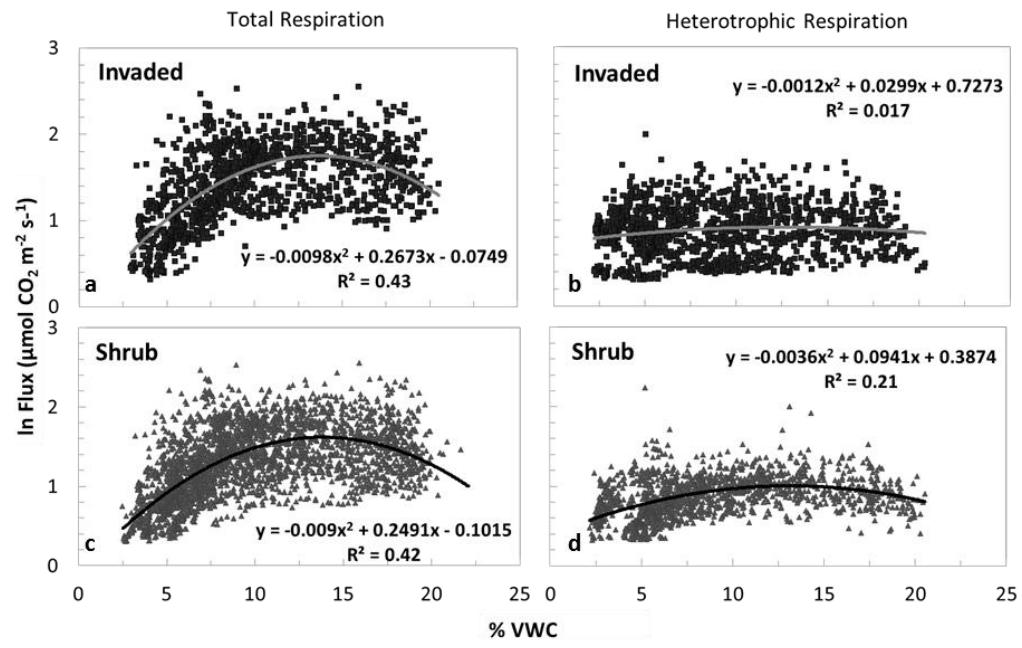

Fig. 4. The relationship between daily average soil moisture (VWC), daily average Rt (left) and $\mathrm{Rh}$ (right) in invaded (top) and shrub (bottom) areas. Flux rates are on a log scale. 


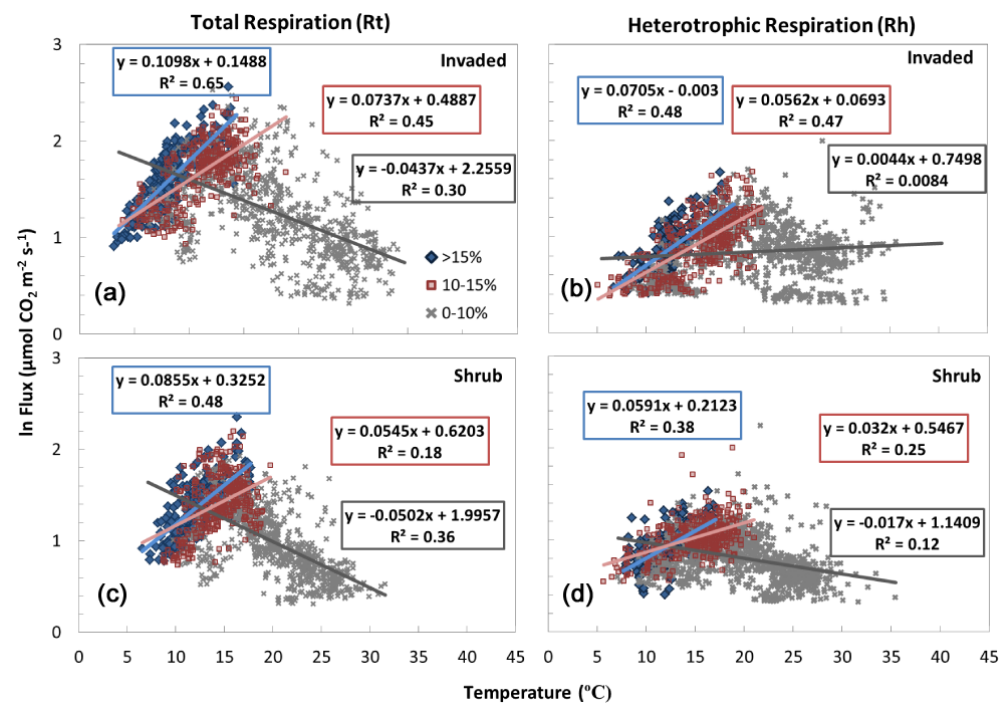

Fig. 5. The relationship between daily average soil temperature $\left({ }^{\circ} \mathrm{C}\right)$, daily average Rt (left) and $\mathrm{Rh}$ (right) in invaded (top) and shrub (bottom) areas. The data has been split into VWC $>15 \%$ (red squares), $10-15 \%$ (blue diamonds) and $<10 \%$ (grey xs) to demonstrate the dependence of the respiration response to temperature on soil moisture content. Note the altered temperature threshold in invaded areas $\left(\mathrm{Rt}=18^{\circ} \mathrm{C}\right.$ and $\mathrm{Rh}=21^{\circ} \mathrm{C}$ ) compared to shrubs (Rt $=15^{\circ} \mathrm{C}$ and $\mathrm{Rh}=16^{\circ} \mathrm{C}$ ). Flux rates are on a log scale.

6373

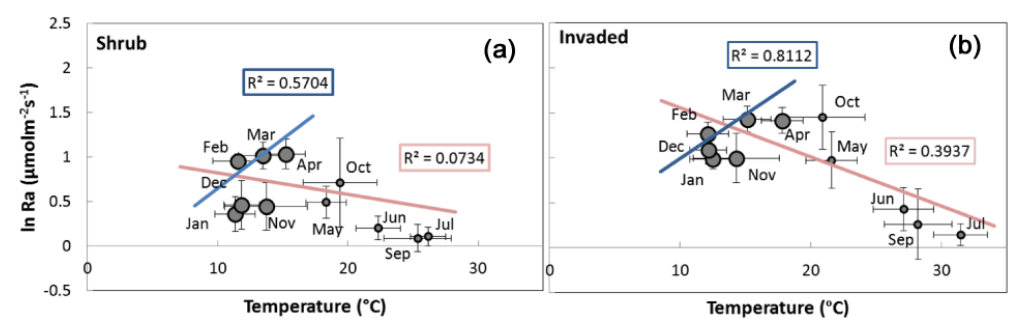

Fig. 6. Relationship between Ra and temperature in shrub (a) and invaded (b) areas grouped by month and VWC. For clarity, each point is the monthly average of Ra and temperature; standard deviation bars show the spread of the data. The size of bubbles indicates average monthly soil moisture: large VWC $>10 \%$, small VWC $<10 \%$. Trend lines were based on daily average $\mathrm{Ra}(\mathrm{Rt}-\mathrm{Rh})$ and temperature from the four paired $\mathrm{Rt}$ and $\mathrm{Rh}$ replicate chambers in each vegetation type. Shrub $\mathrm{Ra}$ fell below the temperature response line in the winter months of November, December and January. 

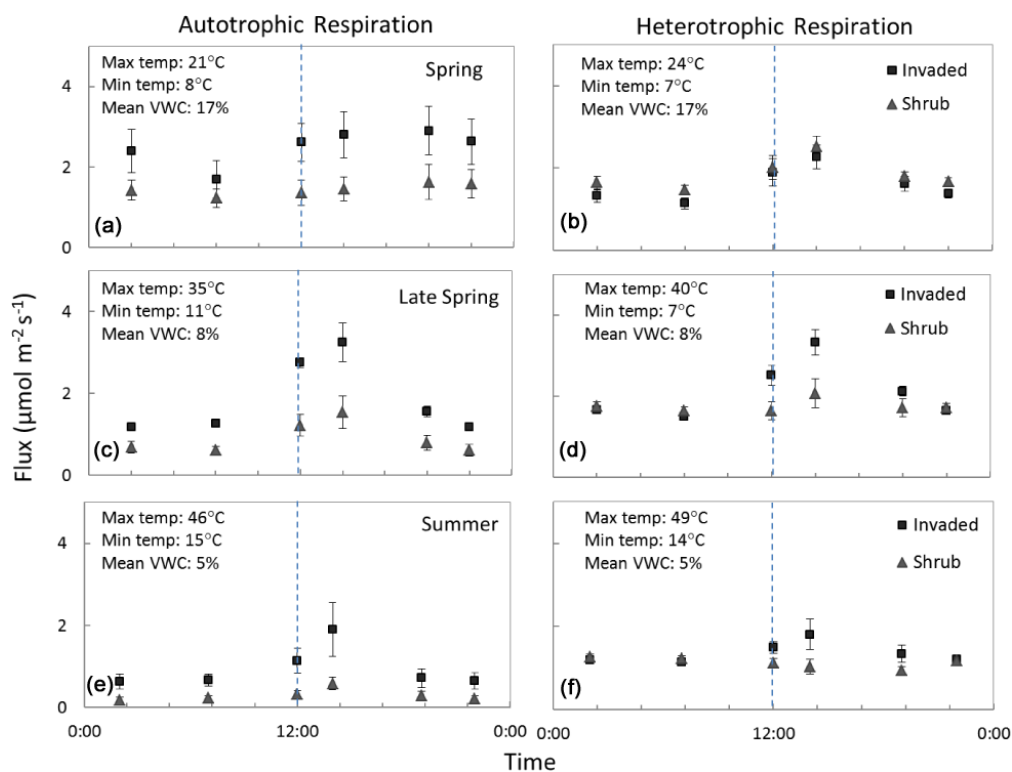

Fig. 7. Diurnal Ra (left) and Rh (right) for shrub (grey triangles) and invaded (black squares) areas in distinct parts of the growing season during 2010 Spring (11-21 February), Late Spring (1-10 May) and Summer (1-10 June). Each time point is an average value over ten days and error bars show standard error based on four replicate chambers. 